This article was downloaded by: [Temple University Libraries]

On: 22 April 2015, At: 15:07

Publisher: Routledge

Informa Ltd Registered in England and Wales Registered Number: 1072954

Registered office: Mortimer House, 37-41 Mortimer Street, London W1T

3J H, UK

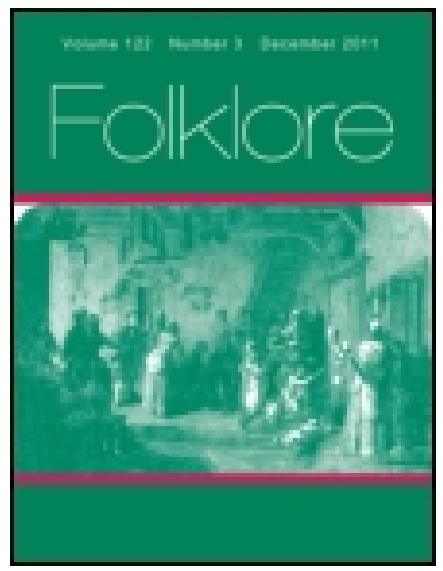

\title{
Folklore
}

Publication details, including instructions for authors and subscription information:

http:// www. tandfonline.com/loi/ rfol20

\section{Amulets from Costers' Barrows in London, Rome, and Naples}

E. Lovett

Published online: 14 Feb 2012.

To cite this article: E. Lovett (1909) Amulets from Costers' Barrows in London, Rome, and Naples, Folklore, 20:1, 70-71, DOI: 10.1080/ 0015587X.1909.9719861

To link to this article: http:// dx. doi. org/ 10.1080/0015587X.1909.9719861

\section{PLEASE SCROLL DOWN FOR ARTICLE}

Taylor \& Francis makes every effort to ensure the accuracy of all the information (the "Content") contained in the publications on our platform. However, Taylor \& Francis, our agents, and our licensors make no representations or warranties whatsoever as to the accuracy, completeness, or suitability for any purpose of the Content. Any opinions and views expressed in this publication are the opinions and views of the authors, and are not the views of or endorsed by Taylor \& Francis. The accuracy of the Content should not be relied upon and should be independently verified with primary sources of information. Taylor and Francis shall not be liable for any losses, actions, claims, proceedings, demands, costs, expenses, damages, and other liabilities whatsoever or howsoever caused arising directly or indirectly in connection with, in relation to or arising out of the use of the Content.

This article may be used for research, teaching, and private study purposes. Any substantial or systematic reproduction, redistribution, reselling, loan, sub-licensing, systematic supply, or distribution in any form to anyone is 
expressly forbidden. Terms $\&$ Conditions of access and use can be found at http://www.tandfonline.com/page/terms-and-conditions 
up, falls upon a graduated scale on the inside of the inner ring, from which the time can be read off.

E. Lovetr.

\section{Amulets from Costers' Barrows in London, Rome, AND NAPLiSS.}

(WITI PLATR III.)

(Read at Meeling, November $19 t h, 1908$.

Ir is a common idea that few traces of folk-beliefs can be found in great cities, but my own experience is that, at any rate for the seeker after amulets, there is no better hunting ground than the hawkers' handbarrows in the poorest parts or slums of such dense aggregations of people as London, Rome, and Naples. In a visit to Italy last summer I obtained a large number of amulets used by the poorer people in Rome and Naples, and Fig. 9 (Plate III.) shows a group of purchases in these cities. The amulets were found, mixed with ex votos and modern religious medals and symbols, for sale, not to the visitor and curio-hunter who rarely invade the slums, but to the poor city dweller and to the peasant visiting the city. The first and third in the top row are metal wavy horns; the second is a tusk; the three in a vertical line on the extreme right and the one in the bottom left-hand corner are artificial horns cut from pearl shells; the largest object is an artificial horn cut from the lip of a conch shell; and the four remaining objects are two pincers of a crab of different sizes, a tooth, and the core of a goat's horn. The general resemblance of these amulets to those shown in the upper part of the Plate is quite obvious, although the group in Fig. 8 was collected from the costers' barrows in the poor man's markets of London.

For many years I have been in touch with some of the Iondon street dealers in unconsidered trifles, and $I$ am much surprised to find how much they know as to the reasons for carrying certain amulets. Phallic symbols, such as the glass and cornelian drops 
PLATE III.

FIG. 8.

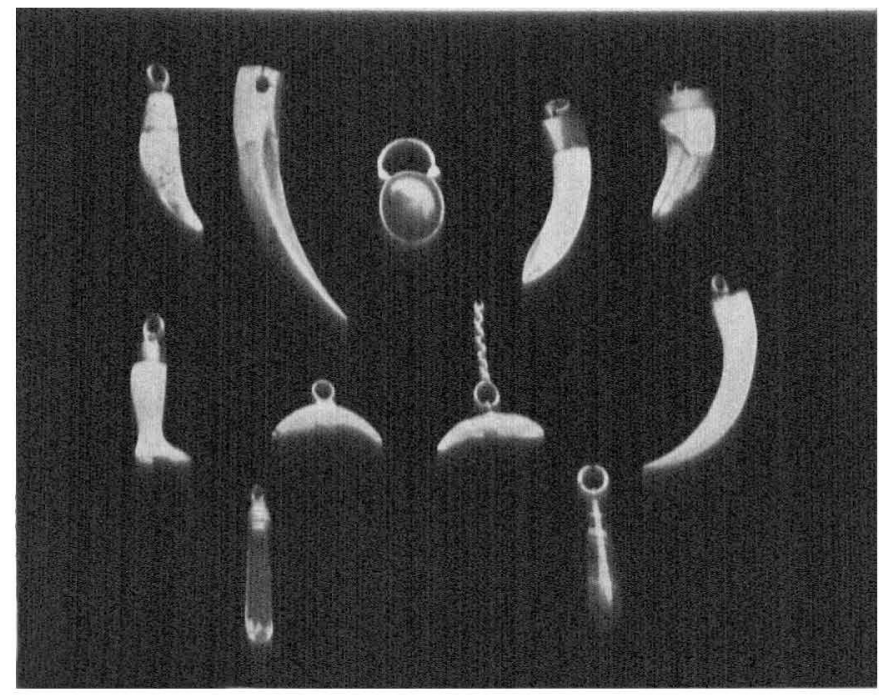

FIG, 9.

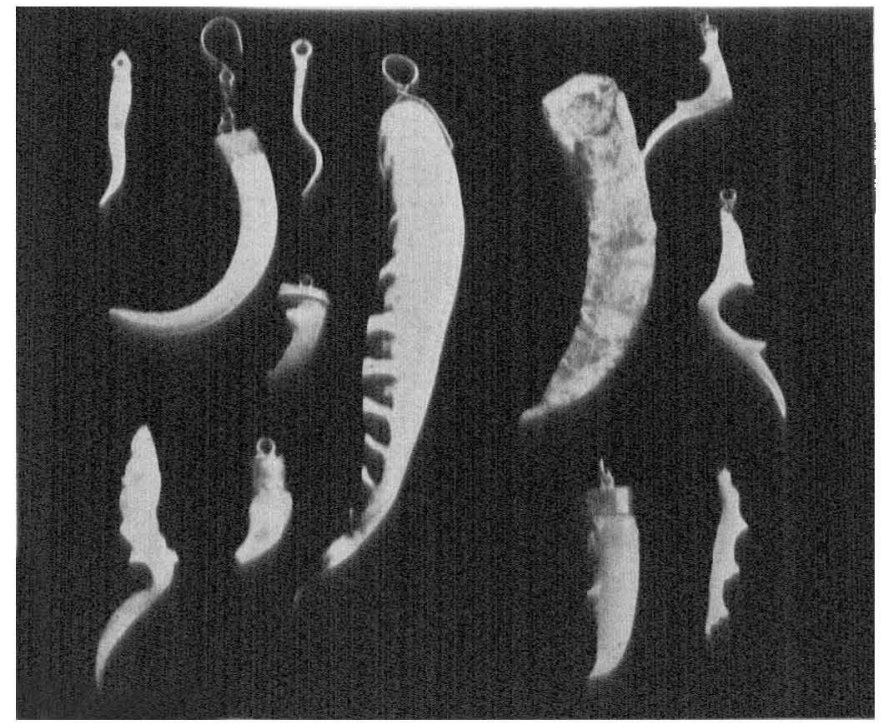

Leomardson so Ca. 
in the bottom row in Fig. 8, are quite well understood, although their descriptions are somewhat crude. Pendants of tusks or of the canine teeth of some animal, such as the four shown in the top row in Fig. 8, are, I am told, largely bought as a protection by men who tend wild animals in shows etc. The middle object in the top row is a cornelian mounted in metal and worn by Jewesses as a charm against the evil eye, and the second row consists of a boot, two canine teeth, and a tusk. Any charm which is of uncertain use is invariably said to be "for luck." Fossil belemnites and nodules of iron pyrites are always called "thunderbolts." I failed to trace any "thunderbolts" in Rome or Naples, but
found tusks and teeth as pendants in great quantities, as well as phallic amulets in coral, shell, bone, and metal. The latter amulets are so common in London also that $I$ am inclined to think that they are probably brought here by the numerous
Neapolitans who seek to supply us with chestnuts in winter,
ice-cream in ice-cream in summer, and music in both. In Naples such amulets are often seen in wear, and almost every shop for the poor has, hanging up, one or more evil-eye charms, such as a glove stuffed and with the two middle fingers and thumb stitched to the palm, so that the other fingers make the sign of the horns, the horses and bedecked and carts of the peasants, which are sometimes so In Rome with amulets as to look like small travelling museums. with a little typical cart amulet is a ram's horn painted blue and Rome, also, I met at its tip. In one of the poorest alleys of who had suspended an itinerant seller of some sort of sweet stuff his tray, the core of a from the shoulder cord which supported from the right in the goat's horn, shown as the second object Without any in the top row of Fig. 9, as an evil-eye charm. acquired this wecimen, and left him gazing after me with sur-
prise; prise; perhaps I was in his fancy a proper candidate for a
lunatic asurlunatic asylum owing to my lavish expenditure.
and

E. Lovetr. 